\title{
The Analysis of Amil Zakat Institution/Lembaga Amil Zakat (LAZ) Accountability toward Public Satisfaction and Trust
}

\author{
Zulfikar Ali Ahmad', Rusdianto ${ }^{2}$ \\ ${ }^{1}$ STIE YKPN, Yogyakarta, Indonesia \\ ${ }^{2}$ Universitas Ahmad Dahlan, Yogyakarta, Indonesia \\ zulfikar.ali.ahmad15@gmail.com¹, rusdianto@act.uad.ac.id²
}

Masuk: 17 Juli 2018; Diterima: 4 Desember 2018; Terbit: 18 Desember 2018

\begin{abstract}
Indonesia has a high potency of zakat fund but the result of its collection shows the great gap compared with the potency. The current issue of Amil Zakat Institution/Lembaga Amil Zakat (LAZ) is about their public trust and public satisfaction. The aim of the research is to examine an impact of LAZ's accountability on public satisfaction and public trust among muzakki in Indonesia. This research collects data using questionnaire from muzakki who paid their zakat in LAZ's. This study uses SEM-PLS to analyze data. The result shows (1) significant influence on the LAZ's accountability to public satisfaction, (2) public satisfaction on LAZ has a significant influence to public trust.
\end{abstract}

Keywords: accountability; amil zakat institution; public satisfaction; public trust

\begin{abstract}
Abstrak
Indonesia memiliki potensi dana zakat yang tinggi, namun hasil dari pengumpulannya menunjukkan ada perbedaan yang besar dibandingkan dengan potensinya. Permasalahan yang dihadapi oleh lembaga amil zakat (LAZ) sekarang adalah terkait dengan kepercayaan publik dan kepuasan publik. Tujuan penelitian ini adalah menguji pengaruh akuntabilitas LAZ terhadap kepuasan publik dan kepercayaan publik. Penelitian ini mengumpulkan data menggunakan kuisioner dari muzakki yang membayar zakat di LAZ. Penelitian ini menganalisa data yang terkumpul menggunakan SEM-PLS. Hasil penelitian menunjukkan (1) adanya pengaruh yang signifikan dari akuntabilitas lembaga amil zakat terhadap kepuasan publik, (2) kepuasan publik atas lembaga amil zakat mempunyai pengaruh signifikan atas kepercayaan publik.
\end{abstract}

Kata Kunci: akuntabilitas; lembaga amil zakat; kepuasan publik; kepercayaan publik 


\section{INTRODUCTION}

Indonesia has a high potency of zakat fund to overcome poverty. Based on the research conducted by Firdaus, Beik, Tony, and Juanda (2012), the potency of zakat in Indonesia reaches $\mathrm{Rp} 217$ trillion. This is equal to $11,45 \%$ of Indonesia national income in 2018. However, National Zakat Agency (BAZNAS) Statistic Book of 2017 showed that zakat fund's collection in 2016 only reached Rp 5 trillion.

The gap between zakat potency and its realization becomes challenge to amil zakat in order to maximize the potency. Amil Zakat Institution/Lembaga Amil Zakat (LAZ) and other stake holders have taken many efforts to increase zakat collection like maintaining muzakki's trust in zakat organization. As an intermediary organization that bridges the individuals and companies as muzakki and the beneficiaries, LAZ is advised to provide information on a frequent basis, specific and broad (Therkelsen, 2011). The information such as financial report of LAZ is sent directly to muzakki, website or newspaper (Rintasari, 2010).

As a non-governmental organization (NGO), zakat organization has some issues addressed on fund management (Dixon, Ritchie, \& Siwale, 2006; Fahrudin, 2003; Goddard \& Assad, 2006; Budiman, 2011). Low accountability is shown by zakat report just addressed to muzakki (Goddard \& Assadd, 2006) and low supervision to fund distribution (Dixon et al. 2006). Accountability can increase public trust in LAZ's ability when they know how LAZ manages zakat fund.

A study by PIRAC (2007) showed that $47 \%$ people refuse to give donation because of their distrust of LAZ. The case shows that trust is an important factor encouraging people to donate. Handriana (2016) shows that trust is a factor that plays an important role in shaping the muzakki's intentions to keep relating to the LAZ. Another study by Connoly and Kelly (2011) explains that accountability is an important key to maintain the organization stability.

Recently, the interest in research of accountability and public trust on nongovernmental organization is increased. Other researchers about non-governmental organization (NGO) are increased as well (Sloan, 2009; Saxton \& Guo, 2011; Dumont, 2013; Coule, 2015; Cordery \& Baskerville, 2011).

There are some problems faced by a non-government organization, they are also experienced by LAZ. It encourages a researcher to conduct a study on accountability perception of LAZ. Some researchers that conducted related study are Huda and Sawardjuwono (2013), Endahwati (2014), Ihsan and Gustina (2008).

Most studies in the field of zakat accountability focus only on internal perspective, from LAZ. However, there is no previous study that has examined zakat accountability from muzakki as external perspective. Thus, this study follows Fard and Rostamy (2007) and modifies it how to examine the citizens by looking at their government accountability to know the role of LAZ accountability from muzakki perspective. The aim of this study is particularly to investigate the effect of LAZ accountability on public satisfaction and trust. Society needs a good accountability from LAZ to evaluate its performance. Through the evaluation, society can determine their satisfaction and trust toward LAZ.

The study has contribution to the literature in three ways. First, extending the literature on accountability of LAZ which predominantly focuses on internal perspective by examining the effect of LAZ accountability on public trust by external perspective. 
Second, public satisfaction as an intervening variable, we provide evidence of the relationship between accountability and trust, whether they have direct or indirect effects. Third, as evidence of relationship between two variables, this study is expected to provide input to zakat management institution to pay attention to accountability that will have implication on service society satisfaction.

\section{The Accountability of LAZ}

LAZ as Non-Governmental Organization (NGO) that is not profit orientation has a different characteristic from that of commercial organizations. Moreover, the majority of accounting literature takes commercial organization perspective to explain accountability (Gray, Bebbington, \& Collison, 2006). Gray et al (2006) explain two implications from different perspective. First, NGO is social organization type, and people who control and donate fund to an organization are already separated from mustahiq. This case also occurs on LAZ. It is divided into two, namely zakat collector (amil) and zakat payer (muzakki) with mustahiq.

Second, LAZ as NGO does not have "bottom line" like profit/loss in a commercial organization. In a commercial organization, financial measurement dominates all performance measurement and accountability. LAZ as part of NGO is not under intense pressure to carry out accountability.

Generally, accountability is a form of formal responsibility for the performance of one party to others (Romzek \& Dubnick, 1987). Accountability emerges as a logical consequence of the relationship between owner and agent which is the implementation of agency theory. Owners in the context of LAZ are: (1) muzakki, munfiq, and mushaddiq; (2) syariah board or supervisory board; (3) God. The agent in the context of LAZ is the manager or amil (Triyuwono \& Roekhuddin, 2000). In practice, the owner gives full authority to the agency to carry out operational activities of the organization and consequently the agent must be accountable for its activities to the owner.

Accountability according to Law of the Republic of Indonesia No. 23, 2011 is one of the principles of zakat management in Indonesia. The purpose of accountability contained in the explanation of Law of the Republic of Indonesia No. 23, 2011 article 2 is that the management of zakat can be accessed by a community. The accountability of LAZ is also regulated in articles 71, 72, and 78 of the Law of the Republic of Indonesia No. 14, 2014.

International Financial Report Standard (IFRS) 109 on zakat accounting and charity also explains about something that must be revealed by LAZ. IFRS 109 states the disclosures performed by amil related to zakat transactions are: (a) zakat disbursement policy; (b) the policy of dividing between amil funds and non-mandatory funds on the receipt of zakat; (c) the method of determining the fair value used for zakah receipt in the form of noncash assets; (d) details of the amount of disbursement of zakah funds which include the amount of management expenses and the amount of funds received directly by mustahiq; and (e) a special relationship between amil and mustahiq. In addition, amil must also disclose the existence of non-halal funds if any and disclose regarding the policy on the receipt and distribution of funds, the reasons, and amounts. Amil's performance on the receipt and distribution of zakat funds and charity funds must also be disclosed. 


\section{Public Satisfaction}

Public satisfaction has a major role in organizational success, including LAZ. Customer satisfaction can increase organizational trust. Zeithaml, Bitner, and Gremler (2009) define customer satisfaction as a customer response to the evaluation of perceived mismatch between expectations and actual performance.

Consumer satisfaction is the comparison between reality and expectations received from a product or service. When performance is lower than customer expectations, it is resulting in dissatisfaction. However, if the performance is satisfied or exceeds from expectations, it leads to satisfaction. Satisfied customers will conduct the activities of re-channeling funds at LAZ. In addition, they will tell others about the good experience of the service of the zakat management organization.

Customer satisfaction is a customer's perception of a single service experience (Parasuraman, Zeithaml, \& Berry, 1988). Consumer satisfaction can only be achieved by providing services quality to its customers. Consumer satisfaction will be fulfilled if the process of delivering services from the provider to the consumer in accordance with what the consumer perceives.

\section{Public Trust and Zakat Institution}

Trust is a multidisciplinary concept with varied definitions (Grimmelikhuijsen, 2012). Lewicki, McAllister, and Bies (1988) define trust as confidence and a positive expectation of the behavior of others and mistrust as a distrust and a negative expectation of the behavior of others. From this definitions, trust is viewed as the perceived trustworthiness of another. For a government case, Grimmelikhuijsen (2011) used three dimensions of perceived trustworthiness namely preceived competence, perceived benevolence, and perceived honesty.

On this paper, we used three dimensions of perceived trustworthiness as used by Grimmelikhuijsen (2011) in context of zakat organization. Perceived competence refers whether people think that LAZ organization is capable, effective, skillful, and professional in making decisions. Perceived benevolence refers whether people think that LAZ really cares about the citizens living in the local area. Perceived honesty as LAZ is perceived to keep commitments and tell the truth.

As nonprofit organization, trust is an important base for LAZ to achieve their objective. Handriana (2016) stated that the intention of muzakki to continue maintaining LAZ is influenced by the trust of muzakki in institution. A trustworthy charity in this case, according to Yang, Brennan, and Wilkinson (2014) is the one that meets the expectations of the public. LAZ must work hard to investigate and reach the expectations of the public in their performance to win public trust.

The existence of this trust will increase the loyalty of the muzakki to pay zakat in zakat management institutions so that the sustainability of the program and the existence of the institution will be maintained. People will be more confident to pay their zakat funds to zakat management institutions with the trust built LAZ.

\section{Accountability, Satisfaction, and Trust}

Public trust is an important issue in organizational management and many researchers have focused on this issue (Denhard, 2002). Fard and Rostamy (2007) reveal that public accountability has a positive effect on public satisfaction that can increase 
public confidence. Satisfaction is formed from good service and accountability.

Some literatures indicate that there are several factors that influence public trust, and some researchers indicate that one of the factors that can reduce public trust is the lack of accountability of an organization (Fard \& Rostamy, 2007). Satisfaction is a mediating variable in relationship between accountability and the quality of service and public trust, but it is possible that accountability and service quality variables directly influence public trust. Accountability in this research is how LAZ is accounted for everything related to society which is divided into financial accountability and performance accountability. Therefore, the following are hypotheses that the authors stated:

H1a. Financial accountability of LAZ has a positive effect on public satisfaction.

H1b. Performance accountability of LAZ has a positive effect on public satisfaction.

H2. Public satisfaction has a positive effect on public trust.

H3a. Financial accountability of LAZ has a positive effect on public trust mediated by public satisfaction.

H3b. Performance accountability of LAZ has a positive effect on public trust mediated by public satisfaction.

This study model is based on Fard and Rostamy (2007) model with some modifications. Fard and Rostamy (2007) examine the effect of accountability on public trust mediated by satisfaction. The model of the study is on figure 1 .

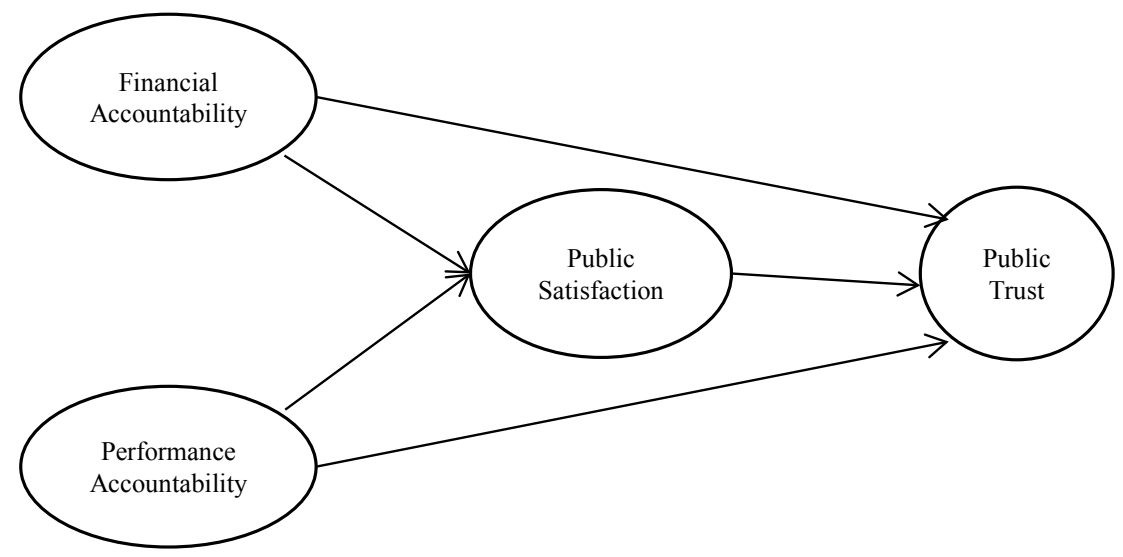

Figure 1. Model of the Study

\section{RESEARCH METHOD}

\section{Sample and data collection}

The data of this study were collected through questionnaires both online and offline. The populations of this study are people who pay zakat (muzakki) at LAZ in Indonesia.

There are two sources of data used in this study, 90 from online and 6 offline questionnaires. One questionnaire was eliminated because it was not complete. Finally, 
we used 95 samples. The result of analysis of respondents' characteristics showed that most of them are 20-30 years old (65\%) then followed by $31-40$ years old $(26 \%) .44 \%$ of respondents pay zakat more than 5 times.

\section{Measurement Instruments}

Dependent variable of this study is public trust, and independent variable is accountability and public satisfaction. Accountability is divided into two parts, financial accountability and performance accountability. Accountability is measured with 10 items and 5 points of scale by Rahmawati (2013). Public satisfaction is measured with 4 items and 5 points of scale developed by Taylor and Baker (1994). Public trust is measured with 11 items and 5 points of scale from McKnight, Choudury, and Kacmar (2002) used by Grimmelikhuijsen (2012).

To analyze hypotheses, we use Structural Equation Modeling by Partial Least Square Approach (SEM-PLS). PLS is part of Structural Equation Modelling (SEM) based on variance to test measurement model and structural model simultaneously (Hartono \& Abdillah, 2009). This variants are based on SEM, because it can predict the theory rather than covariant based on SEM to test the theory. SEM-PLS is used because it can estimate a model with relatively small sample size, and it does not need assumption requirement such as normality and goodness of fit model, and can be used without robust theory (Sholihin \& Ratmono, 2013). In this study, we used Warp PLS 5.0 software to analyze the data.

\section{RESULT AND DISCUSSION}

\section{Measurement Model Analysis}

Model test of index and $\mathrm{P}$ values show three indicators. The indicators are Average Path Coefficient (APC), Average R-Squared (ARS), and Average VIF (AVIF). Kock (2018) suggests that the P values for the APC, ARS is equal or lower than 0.05 . The result of test shows that the indicators of goodness of fit model are fulfilled. APC values with 0.325 and ARS 0.579 and the P values 0.001 (less than 0.05). As for AVIF value, Kock (2018) ideally suggested that it is equal or lower than 3.3.

Measurement model used to evaluate the relationship between measurements and construct is reliability and validity related to the construct. Measurement analysis showed that all measurements are significant with loading factor more than 0.60 . The result indicates that the measurement has some variants even on the construct, as explained by Chin (1998) loading factor is at least 0.60 and ideally is 0.70 .

Construct validity is measured by convergent validity and discriminant validity. Convergent validity is acceptable if the $\mathrm{P}$ values associated with the loadings is equal or lower than 0.05; and that the loadings is equal or greater than 0.5 (Kock, 2014). The analysis results meet the conditions. Discriminant validity is measured by average variance extracted (AVE). Hulland (1999) explains that AVE is ideal if the value is 0.50 or more than 0.50 . The table 1 illustrates the result of discriminant validity. The result shows that all variable's AVE value is higher than 0.80 . It means the entire construct has good convergent validity. 
Table 1. Discriminant Validity.

\begin{tabular}{lrrrr}
\hline & $\begin{array}{c}\text { Financial } \\
\text { Accountability }\end{array}$ & $\begin{array}{c}\text { Performance } \\
\text { Accountability }\end{array}$ & $\begin{array}{c}\text { Public } \\
\text { Satisfaction }\end{array}$ & $\begin{array}{c}\text { Public } \\
\text { Trust }\end{array}$ \\
\hline Financial Accountability & 0.805 & & & \\
Performance Accountability & $0.825^{*}$ & 0.864 & & \\
Public Satisfaction & $0.563^{*}$ & $0.617^{*}$ & 0.882 & \\
Public Trust & $0.644^{*}$ & $0.706^{*}$ & $0.822^{*}$ & 0.838 \\
\hline
\end{tabular}

Diagonal element: square root of AVE; off-diagonal: correlation between constructs

* Correlation is significant at the 0.01 level (2-tailed).

\section{Structural Model Analysis}

Structure modeling is used to examine the hypothesesis, especially to examine whether it has direct or indirect effect of financial accountability and performance accountability on public trust. We use stepwise approach to analyze structural model (Baron \& Kenny, 1989). First, we examine whether public satisfaction affects public trust. Second, we run PLS with test whether financial accountability or performance accountability affects public trust. Third, we run PLS with inserting public satisfaction as mediating variable like figure 1 . The structural model result can be seen in figure 2 .

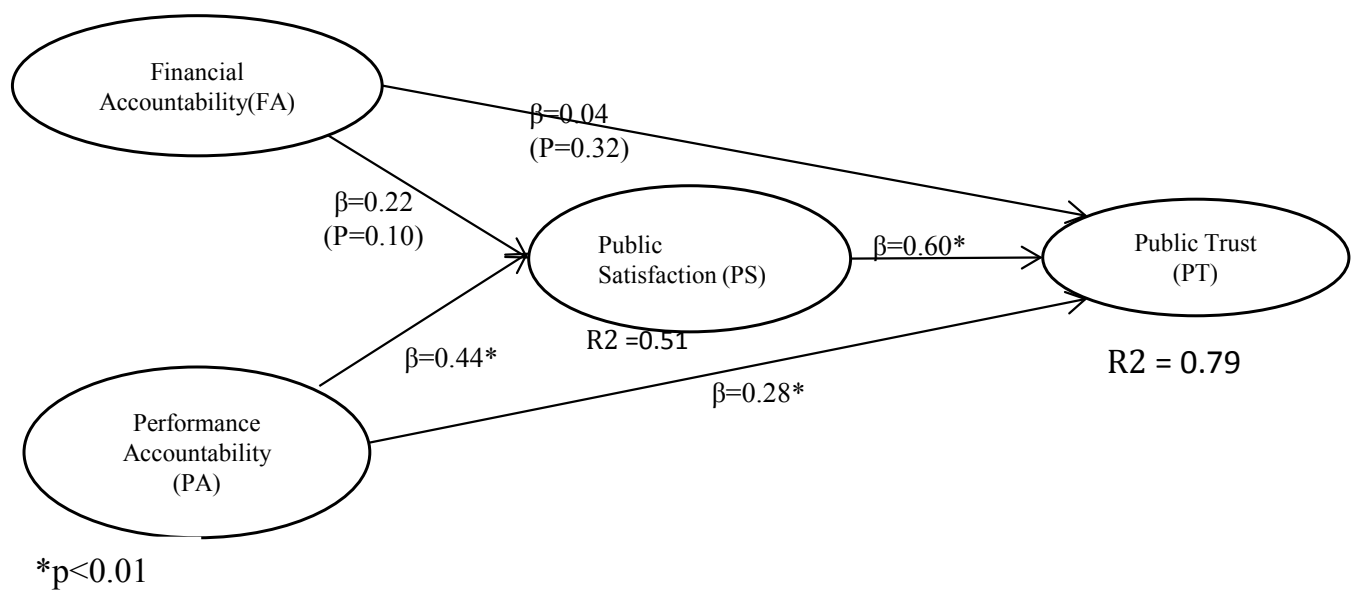

Figure 2. Structural Model Result

We run PLS with financial accountability and performance accountability to public trust to examine hypothesis $1 \mathrm{a}$ and $1 \mathrm{~b}$. The result shows the financial accountability significantly influences public trust $(\beta=0.23 . \mathrm{p}=0.05)$. Thus, the hypothesis of $1 \mathrm{a}$ was positive. The result shows that the financial accountability significantly influences public trust $(\beta=0.58, \mathrm{p}<0.01)$. The hypothesis $1 \mathrm{~b}$ was positive.

It is possible that to pay zakat is related to muzakki's belief. Thus, after muzakki pay zakat, they do have concern to the numbers reported by LAZ (financial accountability). Muzakki also see a real output conducted by LAZ (performance accountability). Like muzakki in NGOs, muzakki who pay zakat at LAZ have an expectation of the increasing assurance (Parsons, 2007). A nonfinancial information (performance accountability) as the number of beneficiaries also affects the donation (Soyer \& Hogarth, 2011). 
To examine the hypothesis 2 , we run PLS with public satisfaction to public trust. The result shows that the public satisfaction significantly influences public trust $(\beta=0.85$. $\left.\mathrm{p}<0.01, \mathrm{R}^{2}=0.74\right)$. It means that hypothesis 2 was positive. The relation between public satisfaction and public trust resulted in $R^{2}=0.74$ proves that the public satisfaction is one of the factors which has a big effect on public trust.

Based on the analysis above, we draw conclusion of mediating used by Sholihin and Ratmono (2013). Because path coefficient of FA-PT on second step is decreased and not significant, we conclude that the relation between financial accountability and public trust was fully mediated by public satisfaction. Hypothesis $4 \mathrm{a}$ was positive. The relation between performance accountability and public trust was partially mediated by public satisfaction. This partial mediation showed that public satisfaction was not the only mediation that has relation between performance accounting and public trust. Therefore, the result of hypothesis $4 \mathrm{~b}$ showed that performance accountability has indirect effect on public trust.

Table 2. Direct and Indirect Effect

\begin{tabular}{lcrrr}
\hline \multicolumn{1}{c}{ Independent Variable } & $\begin{array}{c}\text { Dependent } \\
\text { Variable }\end{array}$ & $\begin{array}{c}\text { Direct } \\
\text { Effect }\end{array}$ & $\begin{array}{c}\text { Indirect } \\
\text { Effect }\end{array}$ & $\begin{array}{r}\text { Total } \\
\text { Effect }\end{array}$ \\
\hline Financial Accountability (FA) & Public Trust (PT) & 0.23 & $0.132^{1}$ & 0.332 \\
Performance Accountability (PA) & & 0.58 & $0.264^{2}$ & 0.844 \\
Public Satisfaction (PS) & & 0.60 & - & \\
${ }^{1}$ Path (FA-PT) $=0.22 \times 0.60=0.132$ & & & & \\
${ }^{2}$ Path (PA-PT) $=0.44 \times 0.60=0.264$ & & & & \\
\hline
\end{tabular}

This study uses VAF method as suggested by Hair, Hult, Ringle and Sartstedt in Sholihin and Ratmono (2013) to test the mediating of SEM-PLS. First, the direct effect (FA-PT and PA-PT) was significant when mediating variable was not included on the model. Second, indirect effect after mediating variable included in the model was significant. Every path was significant (FA-PS, PS-PT and PA-PS). If the indirect effect was significant, it means mediating variable could decrease the direct effect of first test.

Third, we calculate Variance Accounted For (VAF) with formula of indirect effect/ total effect. We get the total effect from the sum of direct effect and indirect effect. The direct and indirect effect between accountability and public trust can be found in table 2. The result of VAF for FA-PT was 0.397 and PA-PT was 0.298 . According to Hair et al in Sholihin and Ratmono (2013), because VAF value was $20 \% \leq$ VAF $\leq 80 \%$, public satisfaction became partial mediating variable for FA-PT and PA-PT link.

\section{CONCLUSION}

This study investigates the effect of LAZ accountability on public satisfaction and public trust. The result showed that LAZ accountability has an effect on public trust. Accountability is divided into two, namely financial accountability and performance accountability. The results showed that financial and performance accountability have significant effect on public trust. These results were in accordance with Fard and Rostamy (2007). 
Because it has significant effect, it means that financial accountability is necessary for zakat management institutions. A study by Nikmatuniayah, Marliyati, and Mardiana A (2017) shows that accountability has positive influence on level of acceptance of zakat fund. PSAK 109 already regulates the disclosure (accountability) which must be done by LAZ. In reality, only a few LAZs obey the regulation. The result of this study also showed that public satisfaction has a significant effect on public trust.

Based on the result of the study, we suggest LAZ to publish its performance report widely. LAZ can publish its performance report on website, magazines, or other media (Therkelsen, 2011). Because the financial accountability does have significant effect, we suggested LAZ to follow the regulation.

This study has three contributions to the literature. We provide some evidences that accountability of LAZ has an effect on public satisfaction and public trust. This study uses sample out of organization perspective to describe accountability.

This study has some limitations. First, the number of sample used is small. The absence of muzakki to collect the data nationally made researcher difficult to estimate the number of muzakki which must be taken as a sample. We suggest the future researchers to take more samples to make it more representative. Second, research model used by in this study is taken from a model developed in the government sector. It made the research model poorly explaining the existing phenomenon in the field.

This study uses two types of accountability, namely financial accountability and performance accountability. For further research, we can take more types of accountability. The existence of more types of accountability will provide more detailed research results, especially the types of accountability required by muzakki.

\section{REFERENCES}

Baron, R. M., \& Kenny, D. A. (1986). The Moderator-Mediator Variable Distinction in Social Psychological Research: Conceptual, Strategic, and Statistical Considerations. Journal of Personality and Social Psychology, 51 (6), 1173-1182. http://dx.doi.org/10.1037/00223514.51.6.1173

Budiman, A. A. (2011). Akuntabilitas Lembaga Pengelola Wakaf. Walisongo: Jurnal Penelitian Sosial Keagamaan , 19 (1), 75-102. http://dx.doi.org/10.21580/ws.19.1.213

Chin, W. W. (1998). The Partial Least Squares Approach for Structural Equation Modeling. in G. A.Marcoulides (Ed.), Modern Methods for Business Research. London, England: Lawrence Erlbaum Associates.

Cordery, C. J., \& Baskerville, R. F. (2011). Charity Transgression, Trust and Accountability. Voluntas: International Journal of Voluntary and Nonprofit Organizations, 22 (2), $197-$ 213. https://doi.org/10.1007/s11266-010-9132-x

Connoly, C., \& Kelly, M. (2011). Understanding Accountability in Social Enterprise Organisations: A framework. Social Enterprise Journal, 7 (3), 224-237. https://doi. org/10.1108/17508611111182386

Coule, T. M. (2015). Nonprofit Governance and Accountability: Broadening the Theoretical Perspective. Non Profit and Voluntary Sector Quarterly. 44 (1), 75-97. https://doi. org/10.1177/0899764013503906

Denhard, R. B. (2002). Trust as Capacity: The Role of Integrity and Responsiveness. Public Organization Review: A Global Journal. 2 (1), 65-76. https://doi. org/10.1023/A:1016027504549

Dixon, R., Ritchie, J., \& Siwale, J. (2006). Microfinance: Accountability from the Grassroots. 
Accounting, Auditing and Accountability Journal, 19 (3), 405-427. http://dx.doi. org/10.1108/09513570610670352

Dumont, G. E. (2013). Nonprofit Virtual Accountability: An Index and its Application. Non Profit and Voluntary Sector Quarterly, 42 (5), 1049-1067. https://doi. org/10.1177/0899764013481285

Endahwati, Y. D. (2014). Akuntabilitas Pengelolaan Zakat, Infak, dan Shodaqoh (ZIS). Jurnal Ilmiah Akuntansi dan Humanika, 4 (1), 1356-1379.

Fahrudin, W. (2003). Akuntabilitas dan Transparansi LSM dalam Proses Transformasi Sosial Menuju Masyarakat Demokratis di Indonesia. CIVIC, 1 (2), 37-48

Fard, H. D., \& Rostamy, A. A. A. (2007). Promoting Public Trust in Public Organizations: Explaining the Role of Public Accountability. Public Organization Review: A Global Journal, 7 (4), 331-344. http://dx.doi.org/10.1007/s11115-007-0041-4

Firdaus, M., Beik, I. S., Tonny, I., \& Juanda, B. (2012). Economic Estimation and Determinations of Zakat Potential in Indonesia. IRTI Working Paper Series WP\# 1433 $\square 07$. Retrieved from Islamic Research and Training Institute website: http:/www.irti.org/English/ Research/Documents/WP/WP-1433-07.pdf

Goddard, A., \& Assad, M. J. (2006). Accounting and Navigating Legitimacy in Tanzanian NGOs. Accounting, Auditing \& Accountability Journal, 19 (3), 377 - 404.http://dx.doi. org/10.1108/09513570610670343

Gray, R., Bebbington, J., \& Collison, D. (2006). NGOs, Civil Society, and Accountability: Making the People Accountable to Capital. Accounting, Auditing and Accountability Journal, 19 (3), 319 - 348. http://dx.doi.org/ 10.1108/09513570610670325

Grimmelikhuijsen, S. (2011). Being Transparent or Spinning the Message? An Experiment into the Effects of Varying Message Content on Trust in Government. Information Polity: The International Journal of Government and Democracy in the Information Age. 16 (1), 3550. doi:10.3233/IP-2011-0222

Grimmelikhuijsen, S. (2012). Linking Transparency, Knowledge, and Citizen Trust in Government: An Experiment. International Review of Administrative Sciences, 78 (1), 50-73. doi:10.1177/0020852311429667

Handriana, T. (2016). Analysis of Donor's Trust and Relationship Commitment in Lembaga Amil Zakat in Indonesia. Journal of Economics, Business, and Accountancy Ventura, 19 (1), 59 - 68. doi:10.14414/jebav.v19i1.529

Hartono, J., \& Abdillah, W. (2009). Konsep dan Aplikasi PLS (Partial Least Square) untuk Penelitian Empiris. Yogyakarta, Indonesia: BPFE

Hair, J., Hult, T., Ringle, C., \& Sartstedt, M. (2013). A Primer on Partial Least Squares Structural Equation Modelling (PLS-SEM). Los Angeles: SAGE.

Huda, N., \& Sawarjuwono, T. (2013). Akuntabilitas Pengelolaan Zakat Melalui Pendekatan Modifikasi Action Research. Jurnal Akuntansi Multiparadigma, 4 (3), 376-388.

Hulland, J. (1999). Use of Partial Least Squares (PLS) in Strategic Management Research: A Review of Four Recent Studies. Strategic Management Journal, 20 (2), 195-204. Retrieved from http://www.jstor.org/stable/3094025

Ihsan M, H., \& Gustina. (2008). Management dan Akuntabilitas Institusi Pengelola Zakat: Suatu Tinjauan Teoritis. Jurnal Akuntansi dan Manajemen, 3 (1), 17-24

Kock, N. (2014). Advanced Mediating Effects Tests, Multi-Group Analyses, and Measurement Model Assessments in PLS-Based SEM. International Journal of e-Collaboration, 10 (1), 1-13. doi: 10.4018/ijec.2014010101

Kock, N. (2018). WarpPLS User Manual: Version 6.0. ScriptWarp Systems ${ }^{\mathrm{TM}}$, Laredo, Texas USA. Retrieved from:cits.tamiu.edu/WarpPLS/UserManual_v_6_0.pdf

Lewicki, R. J., McAllister, D. J., \& Bies, R. J. (1998). Trust and Distrust: New Relationships and Realities. The Academy of Management Review, 23 (3), 438-458, doi: 10.2307/259288 
McKnight D. H., Choudhury, V., \& Kacmar, C. (2002). Developing and Validating Trust Measures for e-Commerce: An Integrative Typology. Information Systems Research, 13 (3), 334-359. doi: 10.1287/isre.13.3.334.81

Nikmatuniayah., Marliyati., \& Mardiana A, L. (2017). Effects of Accounting Information Quality, Accountability, and Transparency on Zakat Acceptance. Mimbar: Jurnal Sosial dan Pembangunan, 33 (1), 62-73. https://doi.org/10.29313/mimbar.v33i1.2029

Parasuraman, A., Zeithaml, V. A., \& Berry, L. L. (1988). SERVQUAL: A Multiple-Item Scale for Measuring Consumer Perceptions of Service Quality. Journal of Retailing, 64 (1), 12-40. Retrieved from https://www.researchgate.net/publication/225083802_SERVQUAL_A_ multiple-_Item_Scale_for_measuring_consumer_perceptions_of_service_quality

Parsons, L. M. (2007). The Impact of Financial Information and Voluntary Disclosures on Contributions to Not-for-Profit Organizations. Behavioral Research in Accounting. 19 (1), 179-196. https://doi.org/10.2308/bria.2007.19.1.179

Pirac. (2007). Public Interest Research and Advocacy Center: Pattern and Potency of Society Donation. Survey at Household at 11 Cities in 2007. Retrieved from www.pirac.org

Rahmawati, N. E. (2013). Pengaruh Akuntabilitas dan Transparansi Pemerintah Daerah Terhadap Kepuasan dan Kepercayaan Masyarakat. Tesis. FEB UGM. Yogyakarta

Rintasari, N. (2010). Persepsi Donatur Mengenai Informasi Akuntansi Organisasi Pengelolaan Zakat. Tesis. FEB UGM. Yogyakarta.

Romzek. B. S., \& Dubnick, M. J. (1987). Accountability in the Public Sector: Lessons from the Challenger Tragedy. Public Administration Review, 47 (3), 227-238. doi: 10.2307/975901

Saxton, G. D., \& Guo, C. (2011). Accountability Online: Understanding the Web-Based Accountability Practices of Nonprofit Organizations. Non Profit and Voluntary Sector Quarterly, 40 (2), 270-295. doi: 10.1177/0899764009341086

Sholihin, M., \& Ratmono, D. (2013). Analisis SEM-PLS dengan WarpPLS 3.0. Yogyakarta, Indonesia: Penerbit Andi.

Sloan, M. F. (2009). The Effect of Nonprofit Accountability Ratings on Donor Behaviour. Non Profit and Voluntary Sector Quarterly, 38 (2), 220-236. doi: 10.1177/0899764008316470

Soyer, E., \& Hogarth, R. M. (2011). The Size and Distribution of Donations: Effects of Number of Recipients. Judgment and Decision Making, 6 (7), 616-628.

Taylor, S. A., \& Baker, T. L. (1994). An Assessment of the Relationship between Service Quality and Customer Satisfaction in the Formation of Consumers' Purchase Intentions. Journal of Retailing, 70 (2), 163-178. https://doi.org/10.1016/0022-4359(94)90013-2

Therkelsen, A. R. (2011). Encounters with Philanthropic Information: Cognitive Dissonance and Implications for the Social Sector. Voluntas: International Journal of Voluntary and Nonprofit Organizations, 22 (3), 518-545. doi:10.1007/s11266-010-9172-2

Triyuwono, I., \& Roekhuddin. (2000). Konsistensi Praktik Sistem Pengendalian Intern dan Akuntabilitas pada LAZIS (Studi kasus di Lazis X Jakarta). Jurnal Riset Akuntansi Indonesia, 3 (2), 151-162.

Zeithaml, V. A., Bitner, M. J., \& Gremler, D. D. (2009). Services Marketing (5th Edition). Singapore: Mc Graw Hill.

Yang, Y., Brennan I., \& Wilkinson, M. (2014). Public Trust and Performance Measurement in Charitable Organizations. International Journal of Productivity and Performance Management, 63 (6), 779 - 796. doi: 10.1108/IJPPM-09-2013-0159 